\title{
Motivation for the development of patents in universities in the state of Pernambuco, Brazil
}

\section{Motivação para o desenvolvimento de patentes em universidades do Estado de Pernambuco}

\author{
Jabson Herber Profiro de Oliveira ${ }^{1}$ (), João Policarpo Rodrigues Lima² ${ }^{(1)}$, \\ Manoel Raimundo Sena Junior ${ }^{3}$ (), Ana Cristina de Almeida Fernandes ${ }^{4}$ (]) \\ ${ }^{1}$ Universidade Federal de Pernambuco - UFPE, Departamento de Ciências Farmacêuticas, Programa de \\ Pós-graduação em Inovação Terapêutica, Recife, PE, Brasil. E-mail: jabson_f16@yahoo.com.br \\ 2Universidade Federal de Pernambuco - UFPE, Departamento de Economia, Programa de Pós-graduação em \\ Economia, Recife, PE, Brasil. E-mail: jprlima@ufpe.br \\ ${ }^{3}$ Universidade Federal de Pernambuco - UFPE, Departamento de Estatística, Programa de Pós-graduação em \\ Estatística, Recife, PE, Brasil. E-mail: manoel@de.ufpe.br \\ ${ }^{4}$ Universidade Federal de Pernambuco - UFPE, Centro de Filosofia e Ciências Humanas - CFCH, Departamento \\ de Ciências Geográficas, Programa de Pós-graduação em Geografia, Recife, PE, Brasil. E-mail: anacf@ufpe.br
}

How to cite: Oliveira, J. H. P., Lima, J. P. R., Sena Junior, M. R., \& Fernandes, A. C. A. (2020).

Motivation for the development of patents in universities in the state of Pernambuco, Brazil. Gestão \&

Produção, 27(4), e4710. https://doi.org/10.1590/0104-530X4710-20

\begin{abstract}
This paper presents the main factors associated with the motivation of researchers from two universities in the state of Pernambuco, Brazil, to develop patents. To do so, the researchers responded to a Likert-scale survey. Through a principal components analysis, it was verified that the factors that serve as barriers to the development of patents in the universities are associated with limitations in the support given by the TTO (Technology Transfer Office) and the amount of benefits offered to researchers. Likewise, the main motivating factors were associated with improvements in the TTO infrastructure and with the expansion of benefits.
\end{abstract}

Keywords: Industrial property; Patent; University; Technological Innovation Center.

Resumo: $\mathrm{O}$ objetivo deste trabalho é apresentar os principais fatores associados à motivação dos pesquisadores de duas universidades do Estado de Pernambuco, para o desenvolvimento de patentes. Para tal, foi solicitado que pesquisadores respondessem um questionário composto por afirmações em escalas likert. Foi efetuada uma análise de Componentes Principais onde constatou-se que os fatores que funcionam como barreiras ao desenvolvimento de patentes nas universidades estão relacionados com limitações no suporte oferecido pelo NIT (Núcleo de Inovação Tecnológica) e a quantidade de benefícios ofertados aos pesquisadores. Assim como, os principais fatores motivadores estiveram relacionados com melhoras na infraestrutura do NIT e a ampliação de benefícios concedidos aos pesquisadores.

Palavras-chave: Propriedade industrial; Patente; Universidade; Núcleo de Inovação Tecnológica.

Received Mar 19, 2019 - Accepted Sept. 16, 2019

Financial support: This study was financed by FACEPE (Foundation for the Support of Science and Technology of the State of Pernambuco) via fellowship.

This is an Open Access article distributed under the terms of the Creative Commons Attribution License, which permits unrestricted use, distribution, and reproduction in any medium, provided the original work is properly cited. 


\section{Introduction}

The university plays the key role of promoting and developing knowledge in a society. In addition, in the new paradigm of the knowledge economy, its role has also been to supply technology to the productive sector (innovation), besides the formation of human resources and research development itself (Haase et al., 2005). Thus, the presence and the activity of the university have been associated with regional development through the innovation provided to the local industry (Wong et al., 2007; Bramwell \& Wolfe, 2008; Cowan \& Zinovyeva, 2013; Osano, 2017).

The literature describes the North American pioneerism in the practice of academic patenting and in the university-industry collaboration in the last decades of the twentieth century (Henderson et al., 1998). This period has also witnessed the expansion of research funding by the private sector throughout American universities (Foltz et al., 2012).

Ever since, the growth of patenting has been associated with changes in both the legislation and the patent system itself (Gallini, 2002) and also by the way universities started interacting with the private sector. Therefore, among the goals of patenting is the recovery of the costs of research (Henderson et al., 1998; Markman et al., 2005).

Thus, North American universities became increasingly involved with private institutions to solve technical and economic issues (Breznitz \& Feldman, 2012). This process promoted innovation and job generation in both the knowledge and the entrepreneurship economies. Such interaction has boosted industry-oriented academic research oriented, with multiplier effects on both the local and the global economy, increasing the number of patent applications, technology licensing and startup creation in the United States. Conversely, government-funded research has decreased (AUTM, 2014).

From the North American experience, the practice of patenting in the academic environment has become a global trend in a way that universities have increasingly sought to protect scientific findings (Agrawal \& Henderson, 2002; Mowery et al., 2001), a phenomenon that includes Brazilian universities (Gullo \& Guerrante, 2006; Mendes et al., 2011; Póvoa, 2008; Silva, 2014).

Recently, there has been a growth in the number of patent applications for Brazilian works in the Brazilian National Institute of Industrial Property (INPI) filed by Brazilian universities (Póvoa, 2008; Gullo \& Guerrante, 2006; Mendes et al., 2011) and also international patent applications (Silva, 2014). This growth has been encouraged by changes in the legal framework such as the Innovation Law (Law No. 10,973/2004, that came into force in 11 October 2005), which provides for the creation of TTO (Technology Transfer Office) in universities (Brasil, 2004; Torkomian, 2009; Dias \& Porto, 2013).

Studies point out knowledge disseminated through events, papers and consultancies as the main sources of information for the development of science and technology (Agrawal \& Henderson, 2002; Cohen et al., 2002). In Brazil, the technology transfer (TT) through patent licensing between universities and firms is still little used when compared with other channels of TT (means by which the knowledge diffusion from the university to the productive sector occurs, following Van Gils et al., 2009) such as consultancy, hiring researchers, reports or even informal information exchange (Póvoa \& Rapini, 2010). However, patents are an important part of technological and open-source information (respecting the grace period) in patent bases. This relevance has increased as universities have sought to engage in this type of legal protection. In addition, the knowledge protected by patents is based on the state of the art, that is, 
all the knowledge hitherto achieved in a given field, in order to generate a new and more profitable technological solution.

Thus, considering the recent practice of academic patenting in Brazilian universities, this paper studies, in a quantitative approach, the motivation for patenting in a less technologically dynamic context, taking as subject a set of researchers from the Federal University of Pernambuco (UFPE) and the Federal Rural University of Pernambuco (UFRPE), two relevant universities located in the Brazilian Northeast.

The literature on patenting refers to specific contexts in other countries that experience a particular economic, academic and innovation panorama. Even researchers that employed a quantitative approach such as Baldini et al. (2007) brought results that do not comprehend the reality of researchers in Brazilian universities. Conversely, Oliveira (2011) is one of the recent Brazilian studies on motivation for academic patenting, but the approach is qualitative and reflects the reality of public universities in the state of São Paulo, Brazil. Hence, there is a gap in empirical studies using primary data in public universities located in states whose economic base is composed predominantly of low-technology sectors. In this regard, this paper aims to understand the main factors associated with the motivation for developing academic patents in contexts of less technological dynamism in Brazil.

\section{Literature review}

The information found in patent documents provide important subsidies for mapping the path of scientific and technological production (Agrawal \& Henderson, 2002) and can also be used as a proxy for innovation (Henderson et al., 1998; Acs et al., 2002; Li et al., 2017; Sharma \& Tripathi, 2017). Data on academic patents are notably recognized as sources of information to measure the economic impact of research funding by innovation agencies in the United States (Kalutkiewicz \& Ehman, 2014; $\mathrm{Li}$ et al., 2017). Therefore, such economic impact is also associated with events that are fundamental for innovation processes to occur, what makes technology commercialization through patent licensing an important part of technology transfer (TT) activities between universities and firms (Arza et al., 2015), being an essential modality for the economic protection and exploitation of inventions related to a given market.

Measuring innovation through patents, although an imperfect proxy (for not entirely reflecting the inventions developed) (Acs et al., 2002), is relevant because it considers the state of the technique for the development of new products and processes. In addition, patents enable greater accessibility to information on the nature of the technology developed and its developers, differently from research contracts and consultancies given by academic researchers. Further, patent applications in universities reflect the attempt of converting scientific findings into technological innovations.

The so-called late-industrializing economies are marked by less intensity in the promotion of innovation, little connection between companies and the other parts of the Innovation System, and a low density of Science \& Technology (S\&T) base in its territory. This makes the importance of the university-industry collaboration to be different in less developed countries and regions, although not less important. In these regions, innovations usually include marginal changes, adaptations and small improvements consistent with the structural characteristics of the more constrained technological dynamics of such regions when compared with those from the dynamic center of innovation production (Pinho \& Fernandes, 2015). In the case of the Northeast 
Region of Brazil, there is a significant disadvantage regarding the absorption of the technology developed in Institutes of Science and Technology (IST), mainly because it is a peripheral region in relation to the great industrial centers of the country (CGEE, 2014). It is in this perspective that patents, as a TT channel, are believed to have different repercussions across economies, especially regarding the frequency and the choice for its use to disseminate technologies.

In the case of Brazilian universities, the practice of patenting is recent and has been encouraged particularly since the mid-1990s after the "Industrial Property Law" and the "Innovation Law" came into force (Póvoa, 2008; Oliveira, 2011).

Unlike in developed economies, patent production and licensing occurs discreetly in developing countries. Therefore, the number of patents licensed to companies and the number of patent applications are uncoupled (OECD, 2004; UNIDO, 2006; Park, 2008; Zuniga, 2011; Ragavan, 2012). This is possibly due to the fact that, in those countries, technological absorption through patents is not cultural as it is in developed countries. Thus, it is assumed that patents are less robust proxies for innovation compared to other university-industry TT channels. This idea is also endorsed by Galván (2017), who came to the same conclusions for the Mexican case.

According to Póvoa (2008), a patent application represents an "indication of inventive activity", that is, when the possibility of economic application of a scientific finding is envisioned, be it a product or a process. In this regard, patent protection represents an expectation of rights to commercial exploitation within a territory for a period of time. More specifically, a patent application signals the interest in the commercialization of the technology developed (Agrawal \& Henderson, 2002).

\subsection{Associated factors}

Due to the increasing relevance of its scientific and technological potential to competitiveness, academic research became an attractive alternative as a source of resources to the promotion of economic development. This factor promoted, on the part of political managers, the incentive to TT and university-industry interaction (Czarnitzki et al., 2011).

The legal framework has been considered a determining factor to promote the commercialization of technologies developed in universities (Haase et al., 2005). Concentrating on the decades of 1980 and 1990, the effects of TT and academic patent policies have been discussed based on the Bayh-Dole Act and the university-industry interaction (Mowery et al., 2002). The literature has pointed out that Technology Transfer Offices (TTO) give great support in universities to the practice of patenting and that the Bayh-Dole Act, a law that encouraged university-industry interaction in the United States in the sense of patenting (Leydesdorff \& Meyer, 2010), has influenced both the legislation of other countries (Japan, Germany, South Korea, the United Kingdom, China among others) and the Brazilian legislation (resulting in the Innovation Law) (AUTM, 2016).

\subsection{Academic patenting: motivations}

The willingness of academics to file a patent application for their scientific findings has been the subject of research in several countries, and the results have showed some similar motivations between them. In Italy, for example, the factors that motivate 
academic inventors to develop patents in the university are related to the support to research development, to knowledge exchange, to obtaining scholarships for them and their students, and to personal benefits such as prestige, visibility and reputation. On the other hand, the obstacles that influence academic patenting the most are related to the lack of support mechanisms, the flaws of technology commercialization, administrative duties in the university, lack of time, personal issues and university culture. Among the measures and mechanisms that could promote academic patenting are the establishment of organizational support mechanisms (the adoption of an internal patent policy), the improvement of institutional framework and the incentive to researchers via personal benefits (Baldini et al., 2007). The potential for patenting in Italian universities together with companies has been associated with the geographical proximity between them. In addition, the presence of innovative companies and the existence of technological clusters in the region have also been highlighted as determinants to this potential (Parente et al., 2011).

In Sweden, some potential motivations for researchers to develop (or not) patents were raised, namely: financial incentives (either public or private); legislation and public policies; academic support (creation of incubators, technological parks, TTOs); business support; participation and formation of networks; R\&D incentives - sources of research funding; personal benefits (financial benefits, prestige and reputation) and intrinsic motivations (ideological interest/willingness with regard to the role of science in the society among others) (Tian, 2015).

In Germany, the results indicate that researchers that seek to improve their reputation engage in both patent applications and scientific dissemination via papers and events. In addition, the reputation factor values publications and patent development, not financial return. This type of subjective interest (reputation/visibility) seems to be more attractive that money. Also, elder researchers seem to be keener on patenting or on choosing between patenting and scientific dissemination than to limit themselves to scientific dissemination. Furthermore, Biology and Medicine researchers seem to opt for practicing both modalities (Göktepe \& Mahagaonkar, 2008).

In Belgium, the partnership between universities and other research institutes and the development of new fields of science, together with TTO activities, have boosted academic patenting. This has occurred especially for Biotechnology (Saragossi \& Potterie, 2003).

In Brazil, in a recent study carried out with researchers from universities in the state of São Paulo, Brazil, Oliveira (2011) pointed out that the factors associated with the motivation or interest of researchers to develop patents comprise: (1) relevance of the industrial application of the field of science to which they belong; (2) social or personal benefits; (3) financial benefits; (4) personal characteristics that may optimize patenting; (5) the point where they are in the academic career; and (6) the possibility of creating opportunities in the industry for the researcher and/or their students, or the interest in solving research issues.

Póvoa (2008) points out some events that may justify the increasing interest for patenting in Brazilian universities in recent years, namely: (1) changes in legislation that enabled industry-university collaboration; (2) incentives to academic inventors; (3) the increase in the technological production resulting from the increase in human resources and academic investments; and (4) the change in the behavior of researchers influenced by international trends and relevant universities abroad.

In the perspective of Brazilian inventors, research funding and the pursuit of recognition in the academic environment are frequently reported factors 
(Closs et al., 2012; Oliveira, 2011). The difficulty of reconciling teaching, research and patenting has also been reported as an obstacle in Brazilian (Closs et al., 2012) and foreign universities (Baldini et sl., 2007).

Those results have been attained in more dynamic contexts considering both scientific density and productive structure and its demand for technology and innovation. Less dynamic contexts such as the state of Pernambuco, Brazil, have not been observed yet and constitute the subject of this paper, whose methodological procedures are presented in the next section.

\section{Methodology}

The survey that originated this paper was submitted to and approved by the Human Research Ethics Committee of the Federal University of Pernambuco (UFPE) (CAAE 47405715.8.0000.5208). It is an unprecedented work on the factors associated with the motivation of researchers to develop patents in universities located in a state in the Brazilian Northeast region.

The target population of the study was researchers from UFPE and the Federal Rural University of Pernambuco (UFRPE) who already filed a patent application. A researcher who filed at least one patent application in Brazil or in another country, for a national or international patent, either lead author or co-author and without limitation of time was considered a patent inventor.

This paper is cross-sectional, quantitative, descriptive and observational, with structured data collection and measurement (Bolfarine \& Bussab, 2005; Gil, 2008). A descriptive study is characterized by the recording of facts or phenomena, as well as their analysis and interpretation, having wide application in several fields of science (Gil, 2008). The term "structured measurement of data" indicates the instrument of data collection; in this case, a questionnaire (Bolfarine \& Bussab, 2005).

One of the advantages of questionnaires is the possibility of measuring the response/opinion of the respondent for a group of individuals questioned about a theme, with the questioning being done in the same way (Huszár et al., 2016).

\subsection{The questionnaire}

The questionnaire used in this work was constructed based on the points addressed in studies (Póvoa, 2008; Torkomian, 2009; Oliveira, 2011; Closs et al., 2012; Dias \& Porto, 2013) and on reports issued by UFPE and UFRPE researchers. Altogether, it is composed of five sections; however, this study will analyze only two. The first one, containing 18 questions, addressed the potential factors that discourage researchers to develop academic patents; the second, with 17 questions, addressed some potential general factors associated with researchers and the TICs in universities that may facilitate and encourage academic patenting and entrepreneurship.

To evaluate the degree of agreement of the statements contained in each section of the questionnaire, a Likert scale valued from 1 (total disagreement) to 7 (total agreement), following Baldini et al. (2007).

Prior to the collection itself, a pre-test (pilot) was performed with seven researchers from UFPE and two intellectual property experts to assess the need for adjustments in the questionnaire. 


\subsection{Data collection}

The sample collection was carried out in the first semester of 2016. To make it feasible, an adaptation to the routine of the participants was made. The following strategies were used to apply the questionnaire:

(1) E-mails were sent to all researchers describing the objectives of the paper and requesting their participation as respondents to the questionnaire in a Microsoft ${ }^{\circledR}$ Word file format. In the same e-mail, a Term of Free and Informed Consent (TCLE) was sent. For each researcher, three attempts were made so as to obtain a return;

(2) The option of handing the questionnaire in person at the workplace (office or laboratory) for immediate application or later collection was given. This option also enabled the opportunity to clear the researchers' doubts.

\subsection{Data analysis}

In the analysis, the internal consistency of the questionnaire data was evaluated using Cronbach's alpha. The coefficient is related to the validity and the reliability of the collection instrument considering the proposed objective (Maroco \& Garcia-Marques, 2006).

To obtain information, multivariate statistics was used to synthesize the data extracted from the sample in order to obtain responses with statistic relevance for the population, filling an existing gap on the theme.

The objective of employing the Principal Components Analysis (PCA) was to obtain the most relevant variables to express the perception and the motivation to engage in academic patenting from the set of original data obtained from the questionnaire. The bootstrap resampling technique was also used to estimate the confidence intervals of the eigenvalues obtained from the transformation of the components, due to the difficulty of obtaining a sufficiently large sample size to ensure the desired reliability.

PCA consists of a method for dimensionality (components) reduction belonging to the group of multivariate statistics techniques. This method considers the variance of an initial n-sized data set to synthesize information between variables (parsimonious summarization) into a set of variables of lower dimensionality from a linear combination (Mardia et al., 1979).

In other words, PCA explains the variance of a data set using spatially organized linear combinations. To do so, it uses the transformation of the correlated variables. It is indicated to study a group with a large number of variables through a set of spatially distributed variables (Mardia et al., 1979; Jolliffe, 2002; Hair et al., 2009; Abdi \& Williams, 2010).

PCA splits total variability (variance) into all the components in a way that the first factor always explains the largest share of the variance and, therefore, the explanatory power of the data. The following components explain the remaining information in lower or equal and sequentially non-increasing shares (Mardia et al., 1979; Jolliffe, 2002; Hair et al., 2009). The fact that the last principal components have less explanatory power makes them less significant in relation to the data set as a whole and, therefore, they can be neglected.

The determination of the principal components is related the cut-off point criterion for accepting the eigenvalues. In the literature, the Kaiser (1958) - which recommends values above 1 - and Jolliffe (1986) - which recommends values above 0.7 - criteria are widely known. 
Orthogonal rotation methods are used to simplify and display a better visualization and interpretation of the spatial relationship between the principal components. Out of the orthogonal rotation techniques, the varimax method is one of the most used. It is given by the maximization of the sum of the variances of the principal components' scores (Hair et al., 2009).

In short, the steps to perform a PCA are: (1) data standardization; (2) calculating the covariance matrix; (3) obtaining eigenvalues and eigenvectors; and (4) defining the elements that compose each principal component.

The contribution (importance) of the variables in the principal components was evaluated following Abdi \& Williams (2010). The squared cosine $\left(\cos ^{2}\right)$ was used as a measure of correlation. $\operatorname{Cos}^{2}$ expresses the importance of a principal component for a given observation/variable. In addition, the loadings for each section were also presented, that is, the correlation between the principal components and the variables. It is a technique that facilitates the visualization of the magnitude of the variables in relation to each principal component (Abdi \& Williams, 2010).

The software used for the analysis was R CRAN x64 3.3.2 through the RStudio v 0.99 .902 interface and the psych, GPArotation, boot, corrplot, FactoMine $R$ and factoextra libraries.

\section{Results}

The average response rate of the questionnaires was around $30 \%$ (Table 1 brings detailed values for both universities). As well as in the population, there was a greater presence of inventors from UFPE in the sample.

Table 1. Detailed response rate.

\begin{tabular}{lccc}
\hline \multicolumn{4}{c}{ POPULATION, SAMPLE AND RESPONDED QUESTIONNAIRES } \\
\hline & Population (\%) & $\begin{array}{c}\text { Responded } \\
\text { questionnaires (\%) }\end{array}$ & $\begin{array}{c}\text { Detailed response } \\
\text { rate (\%) }\end{array}$ \\
\hline UFPE Patent Inventors & $79.23 \%(164)$ & $80.43 \%(74)$ & $45.12 \%$ \\
\hline UFRPE Patent Inventors & $20.77 \%(43)$ & $19.57 \%(18)$ & $41.86 \%$ \\
\hline
\end{tabular}

The data set $(n=92)$ of the sample represents around $45 \%$ of the target population.

The Cronbach's alpha obtained from the responses was above 0.7. Measures above such value are considered reliable to affirm the validity and reliability of the collection instrument (Hora et al., 2010), supporting, therefore, the relevance of the collected data.

In the sample, there has been a predominance of researchers from departments related to Engineering, Health, and Exact and Earth Sciences. A detailed analysis of the profile of the respondents indicates that, out of the Health Sciences researchers, the ones from the Pharmaceutical Sciences stand out. These researchers are very active in both publications and patent developments according to Ferreira (2015).

Table 2 and Chart 1 present a general description of the sample. 
Table 2. Descriptive statistics of the sample $(n=92)$.

\begin{tabular}{lc}
\hline \multicolumn{2}{c}{ CHARACTERIZATION OF THE SAMPLE } \\
\hline & $\begin{array}{c}\text { Patent } \\
\text { inventors }\end{array}$ \\
\hline $\begin{array}{l}\text { Researchers who are or have already been a CNPq Research } \\
\text { Productivity Fellow }\end{array}$ & $47.8 \%(44)$ \\
\hline Level of CNPq Fellows & $25.0 \%(23)-2$ \\
& $10.9 \%(10)-1 D$ \\
\hline Has already been the first-listed inventor of a patent & $4.3 \%(4)-1 \mathrm{~A}$ \\
\hline Researchers who already filed patent applications abroad & $56.5 \%(52)$ \\
\hline $\begin{array}{l}\text { Researchers who filed up to 2 patent applications (Göktepe \& } \\
\text { Mahagaonkar, 2008) }\end{array}$ & $18.5 \%(17)$ \\
\hline $\begin{array}{l}\text { Researchers who filed at least 3 patent applications (Göktepe \& } \\
\text { Mahagaonkar, 2008) }\end{array}$ & $64.1 \%(59)$ \\
\hline \begin{tabular}{l} 
Researchers who developed projects with foreign researchers \\
\hline $\begin{array}{l}\text { Researchers who have already attempted to develop research activities in } \\
\text { partnership with private institutions }\end{array}$
\end{tabular} \\
\hline $\begin{array}{l}\text { Researchers who have already developed projects in partnership with } \\
\text { private institutions }\end{array}$ & $67.4 \%(62)$ \\
\hline
\end{tabular}

Chart 1. Inventor profile by field of science.

\begin{tabular}{|c|c|c|c|c|c|c|}
\hline \multicolumn{7}{|c|}{ INVENTOR PROFILE BY FIELD OF SCIENCE } \\
\hline & Total & $\begin{array}{c}\text { Up to 2 } \\
\text { patent } \\
\text { applications }\end{array}$ & $\begin{array}{c}\text { At least 3 } \\
\text { patent } \\
\text { applications }\end{array}$ & $\begin{array}{c}\text { First } \\
\text { listed } \\
\text { inventor }\end{array}$ & $\begin{array}{c}\text { Has already } \\
\text { attempted } \\
\text { partnerships }\end{array}$ & $\begin{array}{c}\text { Has already } \\
\text { developed } \\
\text { partnerships }\end{array}$ \\
\hline $\begin{array}{c}\text { Agricultural } \\
\text { Sciences }\end{array}$ & $7.6 \%(7)$ & $8.5 \%(5)$ & $6.1 \%(2)$ & $9.6 \%(5)$ & $6.4 \%(4)$ & $4.5 \%(2)$ \\
\hline $\begin{array}{c}\text { Biological } \\
\text { Sciences }\end{array}$ & $17.4 \%(16)$ & $15.2 \%(9)$ & $21.2 \%(7)$ & $13.5 \%(7)$ & $14.5 \%(9)$ & $13.6 \%(6)$ \\
\hline $\begin{array}{c}\text { Health } \\
\text { Sciences }\end{array}$ & $20.6 \%(19)$ & $18.6 \%(11)$ & $24.2 \%(8)$ & $17.3 \%(9)$ & $21.0 \%(13)$ & $15.9 \%(7)$ \\
\hline $\begin{array}{c}\text { Exact and } \\
\text { Earth } \\
\text { Sciences }\end{array}$ & $20.6 \%(19)$ & $17.0 \%(10)$ & $27.2 \%(9)$ & $23.1 \%(12)$ & $22.5 \%(14)$ & $20.4 \%(9)$ \\
\hline $\begin{array}{c}\text { Applied } \\
\text { Social } \\
\text { Sciences }\end{array}$ & $3.2 \%(3)$ & $3.4 \%(2)$ & $3.0 \%(1)$ & $3.8 \%(2)$ & $3.2 \%(2)$ & $4.5 \%(2)$ \\
\hline Engineering & $30.4 \%(28)$ & $37.2 \%(22)$ & $18.1 \%(6)$ & $32.7 \%(17)$ & $32.2 \%(20)$ & $40.9 \%(18)$ \\
\hline Total & $\mathbf{9 2}$ & $\mathbf{5 9}$ & $\mathbf{3 3}$ & $\mathbf{5 2}$ & $\mathbf{6 2}$ & $\mathbf{4 4}$ \\
\hline
\end{tabular}

"Has already attempted partnerships": Researchers who have already attempted to develop research activities in partnership with private institutions; "Has already developed partnerships": Researchers who have already developed projects in partnership with private institutions.

The eigenvalues and their respective confidence intervals were used to define the number of principal componentes (Chart 2). 
Chart 2. Number of principal components by questionnaire section.

\begin{tabular}{|l|c|c|c|c|}
\hline \multicolumn{4}{|c|}{ PRINCIPAL COMPONENTS BY SECTION } \\
\hline \multirow{4}{*}{ Section 1 } & $\begin{array}{c}\text { Principal } \\
\text { Components }\end{array}$ & $\begin{array}{c}\text { Eigenvalues } \\
(\boldsymbol{\lambda})\end{array}$ & \multicolumn{2}{|c|}{$\begin{array}{c}\text { Confidence } \\
\text { Interval }^{* *}\end{array}$} \\
\cline { 2 - 5 } & PC1 & 7.300 & 5.541 & Upper \\
\cline { 2 - 5 } & PC2 & 1.941 & 1.141 & 8.862 \\
\cline { 2 - 5 } & PC3 & 1.612 & 1.119 & 1.959 \\
\cline { 2 - 5 } & PC4 & 1.156 & 0.791 & 1.339 \\
\cline { 2 - 5 } & PC1 & 6.201 & 4.899 & 7.360 \\
\cline { 2 - 5 } & PC2 & 2.541 & 1.255 & 3.170 \\
\cline { 2 - 5 } & PC3 & 1.538 & 1.009 & 1.725 \\
\cline { 2 - 5 } & PC4 & 1.265 & 0.953 & 1.446 \\
\cline { 2 - 5 } & PC5 & 1.068 & 0.868 & 1.266 \\
\hline
\end{tabular}

*In this component, the confidence interval obtained via bootstrap resampling includes a value below 1 , but above 0.7 . Jolliffe (1986) states that values above 0.7 are acceptable. ${ }^{* *}$ Confidence intervals obtained by bootstrap resampling.

In the selection of the eigenvectors of the variables that constitute the principal components, the Hair et al. (2009) criterion was considered. It recommends that, for random samples with 100 individuals, only eigenvectors above 0.55 be considered. In a conservative fashion, the principal components were formed by the variables that obtained eigenvectors above 0.6 .

The first section of the questionnaire is related to the major measures that discourage researchers to develop academic patents. Four principal components were found. These components explain around $65 \%$ of the variance and are formed by the variables highlighted in Chart 3 . The set of variables that constitute PC1 explained $40 \%$ of these questions and is associated with lack of support, culture of the university and lack of support teams in the TIC, whereas PC2 is related to low return and relevance given to the researcher's career and low importance given by institutions and evaluation bodies. PC3 was related to little knowledge of the researcher about patents and traditionalism in scientific dissemination and PC4 was related to the choice of other TT channels, little interest of researchers and limited openness to developing RD\&l projects (Chart 4).

Chart 3. Descriptive statistics and correlation between eigenvectors and the Principal Components' scores for the variables in the first section.

\begin{tabular}{|c|c|c|c|c|c|}
\hline \multirow{2}{*}{ Variables } & $\begin{array}{c}\text { Descriptive } \\
\text { statistics }\end{array}$ & \multicolumn{4}{|c|}{$\begin{array}{c}\text { Principal Components and } \\
\text { eigenvectors }\end{array}$} \\
\cline { 2 - 6 } & Median & PC1 & PC2 & PC3 & PC4 \\
\hline V71 & 6.0 & 0.121 & 0.047 & $\mathbf{0 . 7 7 6}$ & 0.010 \\
\hline V72 & 6.0 & 0.030 & $\mathbf{0 . 6 6 7}$ & 0.143 & 0.334 \\
\hline V73 & 5.5 & 0.044 & $\mathbf{0 . 7 2 7}$ & 0.190 & 0.249 \\
\hline V74 & 6.0 & $\mathbf{0 . 6 0 0}$ & 0.545 & 0.017 & 0.066 \\
\hline V75 & 6.0 & 0.327 & $\mathbf{0 . 8 2 2}$ & 0.169 & 0.060 \\
\hline V76 & 5.0 & 0.439 & $\mathbf{0 . 7 6 3}$ & 0.201 & -0.022 \\
\hline V77 & 6.0 & 0.133 & 0.225 & $\mathbf{0 . 8 3 1}$ & 0.078 \\
\hline V78 & 6.0 & 0.036 & 0.319 & $\mathbf{0 . 8 1 5}$ & 0.158 \\
\hline
\end{tabular}


Chart 3. Continued..

\begin{tabular}{|c|c|c|c|c|c|}
\hline \multirow{2}{*}{ Variables } & $\begin{array}{c}\text { Descriptive } \\
\text { statistics }\end{array}$ & \multicolumn{4}{|c|}{$\begin{array}{c}\text { Principal Components and } \\
\text { eigenvectors }\end{array}$} \\
\cline { 2 - 6 } & Median & PC1 & PC2 & PC3 & PC4 \\
\hline V79 & 6.0 & 0.495 & -0.013 & $\mathbf{0 . 6 5 1}$ & 0.174 \\
\hline V80 & 5.0 & 0.253 & 0.042 & 0.049 & $\mathbf{0 . 6 3 9}$ \\
\hline V81 & 5.5 & $\mathbf{0 . 7 1 1}$ & 0.106 & 0.183 & 0.317 \\
\hline V82 & 6.0 & $\mathbf{0 . 6 6 7}$ & 0.244 & 0.258 & 0.260 \\
\hline V83 & 6.0 & $\mathbf{0 . 8 0 7}$ & 0.255 & -0.050 & 0.139 \\
\hline V84 & 6.0 & $\mathbf{0 . 8 5 1}$ & 0.095 & 0.147 & 0.137 \\
\hline V85 & 7.0 & $\mathbf{0 . 7 1 5}$ & 0.128 & 0.251 & 0.260 \\
\hline V87 & 5.0 & 0.125 & 0.143 & 0.255 & $\mathbf{0 . 7 6 9}$ \\
\hline \% of explained variance & - & $40.5 \%$ & $10.7 \%$ & $8.9 \%$ & $6.4 \%$ \\
\hline \% of accumulated variance & - & 40.5 & 51.2 & 60.1 & 66.5 \\
\hline
\end{tabular}

Rotated component matrix (varimax).

Chart 4. Description of the variables of the principal components in the first section.

\begin{tabular}{|c|c|}
\hline & Factors that discourage the development of academic patents \\
\hline \multirow{6}{*}{ PC1 } & V74 - Little incentive/support from the university \\
\hline & $\begin{array}{l}\text { V81 - Lack of experts in intellectual property rights in the ICT to elaborate contracts } \\
\text { and resolve litigation cases }\end{array}$ \\
\hline & $\begin{array}{l}\text { V82 - "Pro-innovation and entrepreneurship" mindset still underdeveloped in the } \\
\text { university }\end{array}$ \\
\hline & V83 - Lack of advisory from experts in writing patent applications \\
\hline & $\begin{array}{l}\text { V84 - Lack of a team of experts in evaluating the potential, stage and valuation of } \\
\text { the technology developed in the university }\end{array}$ \\
\hline & V85 - Lack of a marketing team for the technological portfolio of the university \\
\hline \multirow{4}{*}{ PC2 } & $\begin{array}{l}\text { V72 - Little possibility of return/gains from patent applications compared to the } \\
\text { publication of papers }\end{array}$ \\
\hline & V73 - Little relevance for the progression of the researcher's career in the university \\
\hline & V75 - Little relevance given by the CAPES evaluation to patents \\
\hline & V76 - Little relevance given by the CNPq evaluation to patents \\
\hline \multirow{4}{*}{ PC3 } & V71 - Little familiarity with writing patent applications \\
\hline & V77 - Limited market-oriented vision of the researcher \\
\hline & V78 - Purely academic research vision among researchers \\
\hline & $\begin{array}{l}\text { V79 - Little knowledge of the researcher on patents as forms of protection and } \\
\text { dissemination of the knowledge developed in the university }\end{array}$ \\
\hline \multirow[t]{2}{*}{ PC4 } & $\begin{array}{l}\text { V80 - Preference for other TT modalities (for example, consultancy and advisory; } \\
\text { informal information exchange; contracts of R\&D projects; creation of academic } \\
\text { spinoffs; research joint ventures) }\end{array}$ \\
\hline & V87 - Little interest among researchers in developing RD\&I projects \\
\hline
\end{tabular}

Table 3 displays the correlation between the variables in the first section and the principal components in descending order. Table 4 presents the variables that were most correlated (strong/moderate correlation with the principal components. 
Table 3. Correlation between the variables in the first section and the principal components.

\begin{tabular}{|c|c|c|c|c|c|c|c|c|}
\hline & \multicolumn{2}{|c|}{ PC1 } & \multicolumn{2}{|c|}{ PC2 } & \multicolumn{2}{|c|}{ PC3 } & \multicolumn{2}{|c|}{ PC4 } \\
\hline & 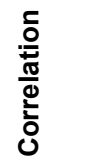 & $\begin{array}{l}\frac{0}{3} \\
\frac{1}{\pi} \\
\frac{3}{2}\end{array}$ & 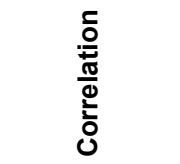 & $\begin{array}{l}\frac{0}{2} \\
\frac{2}{\pi} \\
\frac{1}{2}\end{array}$ & 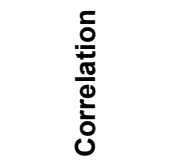 & $\begin{array}{l}\frac{0}{2} \\
\frac{2}{\pi} \\
\frac{1}{2}\end{array}$ & 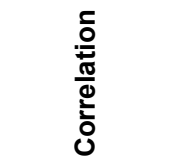 & $\begin{array}{l}\frac{0}{2} \\
\frac{2}{\pi} \\
\frac{1}{2}\end{array}$ \\
\hline v82 & 0.7682 & $<0.000$ & v78 0.6798 & $<0.000$ & v73 0.5263 & $<0.000$ & v87 0.6173 & $<0.000$ \\
\hline v76 & 0.7463 & $<0.000$ & v77 0.6494 & $<0.000$ & v75 0.5030 & $<0.000$ & v80 0.4811 & $<0.000$ \\
\hline v85 & 0.7379 & $<0.000$ & v71 0.6061 & $<0.000$ & v72 0.4915 & $<0.000$ & v88 0.3127 & $<0.001$ \\
\hline v84 & 0.7231 & $<0.000$ & v79 0.2882 & $<0.001$ & v76 0.3994 & $<0.000$ & v86 0.3000 & $<0.001$ \\
\hline v75 & 0.7205 & $<0.000$ & v88 -0.2090 & $<0.001$ & v71 -0.2556 & $<0.001$ & v83 -0.2055 & $<0.001$ \\
\hline v81 & 0.7187 & $<0.000$ & v81 -0.2302 & $<0.001$ & v81 -0.2845 & $<0.001$ & v84 -0.2124 & $<0.001$ \\
\hline v86 & 0.7071 & $<0.000$ & v74 -0.2591 & $<0.001$ & v85 -0.2857 & $<0.001$ & v74 -0.2462 & $<0.001$ \\
\hline v74 & 0.7032 & $<0.000$ & v84 -0.3085 & $<0.001$ & v84 -0.3320 & $<0.001$ & v76 -0.3136 & $<0.001$ \\
\hline v83 & 0.6953 & $<0.000$ & v83 -0.4458 & $<0.000$ & v79 -0.4332 & $<0.000$ & & \\
\hline v79 & 0.6507 & $<0.000$ & & & & & & \\
\hline v78 & 0.5736 & $<0.000$ & & & & & & \\
\hline v77 & 0.5662 & $<0.000$ & & & & & & \\
\hline v73 & 0.5660 & $<0.000$ & & & & & & \\
\hline v87 & 0.5510 & $<0.000$ & & & & & & \\
\hline v72 & 0.5406 & $<0.000$ & & & & & & \\
\hline v80 & 0.4525 & $<0.000$ & & & & & & \\
\hline v88 & 0.4472 & $<0.000$ & & & & & & \\
\hline v71 & 0.4215 & $<0.000$ & & & & & & \\
\hline
\end{tabular}

Loadings, correlation between principal components and the variables (Abdi \& Williams, 2010); strong/moderate correlation (considering values above 0.5$)$; only variables with significant correlation $(\alpha>0.05)$ are presented.

Table 4. Description of variables in the first section that had a moderate/strong correlation with the principal components.

Description of variables in the first section that had a moderate/strong correlation with the principal components

(Factors that discourage the development of academic patents)

\begin{tabular}{ll}
\hline v82 & "Pro-innovation and entrepreneurship" mindset still underdeveloped in the university \\
\hline v76 & Little relevance given by the CNPq evaluation to patents \\
\hline v85 & Lack of a marketing team for the technological portfolio of the university \\
\hline v84 & $\begin{array}{l}\text { Lack of a team of experts in evaluating the potential, stage and valuation of the } \\
\text { technology developed in the university }\end{array}$ \\
\hline v75 & Little relevance given by the CAPES evaluation to patents \\
\hline v81 & $\begin{array}{l}\text { Lack of experts in intellectual property rights in the TTO to elaborate contracts and } \\
\text { resolve litigation cases }\end{array}$ \\
\hline v86 & Little openness of the university with regard to developing RD\&I projects \\
\hline v74 & Little incentive/support from the university \\
\hline v83 & Lack of advisory from experts in writing patent applications \\
\hline v79 & $\begin{array}{l}\text { Little knowledge of the researcher on patents as forms of protection and dissemination } \\
\text { of the knowledge developed in the university }\end{array}$ \\
\hline v78 & Purely academic research vision among researchers \\
\hline v77 & Limited market-oriented vision of the researcher \\
\hline
\end{tabular}


Table 4. Continued...

Description of variables in the first section that had a moderate/strong correlation with the principal components

(Factors that discourage the development of academic patents)

\begin{tabular}{ll}
\hline v73 & Little relevance for the progression of the researcher's career in the university \\
\hline v87 & Little interest among researchers in developing RD\&I projects \\
\hline v72 & $\begin{array}{l}\text { Little possibility of return/gains from patent applications compared to the publication of } \\
\text { papers }\end{array}$ \\
\hline v71 & Little familiarity with writing patent applications \\
\hline
\end{tabular}

The variables that were most correlated with the principal components are in bold type.

The second section of the questionnaire is related to the main factors than can facilitate and encourage the practices of patent development and academic entrepreneurship in the university. Five principal components were found. These explain around $75 \%$ of the data variance and are composed of the variables highlighted in Chart 5. The set of variables that constitute PC1 explained around $35 \%$ of these issues and is associated with the existence of support teams and pro-activity in the TTO, whereas PC2 was related to an increased interest from researchers and companies in the university-industry interaction. PC3 was related to the existence of success cases in the university and increased agility in granting patents, PC4 was related to a increased interest from researchers in RD\&I projects and the existence of partnerships with other universities and PC5 was related to the location of companies close to the university (Chart 6).

Chart 5. Descriptive statistics and correlation between eigenvectors and the Principal Components' scores for the variables in the second section.

\begin{tabular}{|c|c|c|c|c|c|c|}
\hline \multirow{2}{*}{ Variables } & \multirow{2}{*}{$\begin{array}{c}\text { Descriptive } \\
\text { statistics }\end{array}$} & \multicolumn{5}{|c|}{ Principal componentes and eigenvectors } \\
\hline & & PC1 & PC2 & PC3 & PC4 & PC5 \\
\hline V89 & 7.0 & 0.848 & 0.040 & 0.085 & -0.135 & -0.071 \\
\hline V90 & 6.0 & 0.827 & 0.222 & 0.101 & -0.139 & -0.020 \\
\hline V91 & 7.0 & 0.886 & 0.109 & 0.177 & 0.142 & 0.073 \\
\hline V92 & 7.0 & 0.889 & 0.080 & 0.175 & 0.176 & 0.106 \\
\hline V93 & 6.5 & 0.866 & 0.030 & 0.130 & 0.174 & 0.235 \\
\hline V94 & 6.0 & 0.045 & -0.028 & 0.118 & 0.740 & 0.109 \\
\hline V95 & 6.0 & -0.030 & 0.146 & 0.048 & 0.821 & -0.019 \\
\hline V97 & 7.0 & 0.169 & 0.674 & 0.285 & 0.048 & 0.036 \\
\hline V98 & 6.0 & 0.000 & 0.746 & -0.049 & -0.086 & 0.313 \\
\hline V99 & 7.0 & 0.201 & 0.877 & 0.115 & 0.079 & 0.009 \\
\hline V100 & 6.0 & 0.012 & 0.708 & 0.295 & 0.298 & -0.037 \\
\hline V101 & 4.5 & 0.018 & 0.072 & 0.208 & -0.017 & 0.843 \\
\hline V103 & 7.0 & 0.250 & 0.311 & 0.721 & 0.374 & 0.022 \\
\hline V104 & 7.0 & 0.269 & 0.293 & 0.770 & 0.163 & 0.058 \\
\hline V105 & 7.0 & 0.058 & 0.006 & 0.849 & -0.116 & 0.195 \\
\hline $\begin{array}{c}\% \text { of explained } \\
\text { variance }\end{array}$ & - & 36.4 & 14.9 & 9.0 & 7.4 & 6.2 \\
\hline $\begin{array}{c}\% \text { of accumulated } \\
\text { variance }\end{array}$ & - & 36.4 & 51.3 & 60.3 & 67.7 & 73.9 \\
\hline
\end{tabular}

Rotated component matrix (varimax). 
Chart 6. Description of the variables of the principal components in the second section.

\begin{tabular}{|c|c|}
\hline & $\begin{array}{l}\text { Factors than can facilitate and encourage the practices of patent development and } \\
\text { academic entrepreneurship in the university }\end{array}$ \\
\hline \multirow{5}{*}{ PC1 } & $\begin{array}{l}\text { V89 - Promotion, by the TTO, of incentives for researchers to develop projects together } \\
\text { with companies }\end{array}$ \\
\hline & $\begin{array}{l}\text { V90 - Promotion, by the TTO, of incentives for researchers to develop research for the } \\
\text { purpose of commercializing/licensing technologies with companies }\end{array}$ \\
\hline & $\begin{array}{l}\text { V91 - The existence of a specific team in the TTO with employees dedicated to the } \\
\text { marketing of the set of technologies that the university has }\end{array}$ \\
\hline & $\begin{array}{l}\text { V92 - Support of a specific team in the TTO for the marketing of the portfolio and } \\
\text { technological activities of the university }\end{array}$ \\
\hline & V93 - Support of a team for negotiating activities in the TTO \\
\hline \multirow{4}{*}{$\mathrm{PC2}$} & $\begin{array}{l}\text { V97 - Companies should look for universities to engage in partnerships. This can } \\
\text { facilitate and encourage the practice }\end{array}$ \\
\hline & V98 - Researchers in the university should look for companies to engage in partnerships \\
\hline & V99 - There must be a constant university-industry interaction through research groups \\
\hline & $\begin{array}{l}\text { V100 - Increased interest from the researcher in filing patent applications together with } \\
\text { companies }\end{array}$ \\
\hline \multirow{3}{*}{ PC3 } & V103 - Incentive via development agencies through thematic calls \\
\hline & $\begin{array}{l}\text { V104 - Increased frequency of successful TT cases via patent licensing between } \\
\text { university and industry }\end{array}$ \\
\hline & V105 - Increased agility in the process of analysis and granting of patents by the INPI \\
\hline \multirow[b]{2}{*}{ PC4 } & V94 - Increased interest from the researcher in developing RD\&I projects \\
\hline & $\begin{array}{l}\text { V95 - Increase in the interest of the researcher in filing patent applications together with } \\
\text { researchers from other universities }\end{array}$ \\
\hline PC5 & V101 - Companies located close to the university \\
\hline
\end{tabular}

Table 5 displays the correlation between the variables in the second section and the principal components in descending order. Table 6 presents the variables that were most correlated (strong/moderate correlation with the principal components.

Table 5. Correlation between the variables in the second section and the principal components.

\begin{tabular}{|c|c|c|c|c|c|c|c|c|c|c|}
\hline & \multicolumn{2}{|c|}{ PC1 } & \multicolumn{2}{|c|}{ PC2 } & \multicolumn{2}{|c|}{ PC3 } & \multicolumn{2}{|c|}{ PC4 } & \multicolumn{2}{|c|}{ PC5 } \\
\hline & 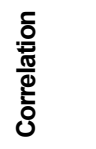 & $\begin{array}{l}\frac{0}{2} \\
\frac{10}{10} \\
\stackrel{1}{2}\end{array}$ & 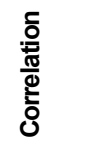 & $\frac{0}{\frac{0}{2}}$ & 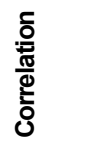 & $\frac{0}{\frac{0}{2}}$ & 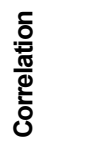 & $\frac{0}{\frac{0}{2}}$ & $\begin{array}{l}\frac{0}{0} \\
\frac{0}{0} \\
\text { ㅎํ }\end{array}$ & $\frac{0}{\frac{0}{2}}$ \\
\hline v102 & 0.8031 & $<0.000$ v100 & 0.5302 & $<0.000$ v94 & 0.5501 & $<0.000$ v95 & 0.4759 & $<0.000$ v101 & 0.7801 & $<0.000$ \\
\hline v92 & 0.7824 & $<0.000$ v95 & 0.3941 & $<0.000$ v95 & 0.4637 & $<0.000$ v94 & 0.3334 & $<0.001$ v96 & 0.4783 & $<0.000$ \\
\hline v91 & 0.7777 & $<0.000$ v98 & 0.3515 & $<0.000$ v103 & 0.2308 & $<0.001$ v96 & 0.2534 & $<0.001$ v98 & 0.2460 & $<0.001$ \\
\hline v103 & 0.7671 & $<0.000$ v99 & 0.3495 & $<0.000$ v102 & 0.2268 & $<0.001$ v99 & 0.2088 & $<0.001$ & & \\
\hline v93 & 0.7458 & $<0.000$ v103 & 0.3178 & $<0.001$ v100 & -0.2053 & $<0.001$ v103 & -0.2170 & $<0.001$ & & \\
\hline v104 & 0.7407 & $<0.000$ v97 & 0.3143 & $<0.001$ v90 & -0.2416 & $<0.001$ v104 & -0.3808 & $<0.000$ & & \\
\hline v90 & 0.6554 & $<0.000$ v102 & 0.2870 & $<0.001$ v97 & -0.3559 & $<0.000$ v105 & -0.7137 & $<0.000$ & & \\
\hline v99 & 0.6143 & $<0.000$ v94 & 0.2565 & $<0.001$ v99 & -0.5230 & $<0.000$ & & & & \\
\hline v97 & 0.5779 & $<0.000$ v104 & 0.2387 & $<0.001$ v98 & -0.5761 & $<0.000$ & & & & \\
\hline v89 & 0.5701 & $<0.000$ v91 & -0.4867 & $<0.000$ & & & & & & \\
\hline v100 & 0.5532 & $<0.000$ v92 & -0.4888 & $<0.000$ & & & & & & \\
\hline
\end{tabular}


Table 5. Contined...

\begin{tabular}{|c|c|c|c|c|c|c|c|c|c|c|}
\hline & \multicolumn{2}{|c|}{ PC1 } & \multicolumn{2}{|c|}{ PC2 } & \multicolumn{2}{|c|}{ PC3 } & \multicolumn{2}{|c|}{ PC4 } & \multicolumn{2}{|c|}{ PC5 } \\
\hline & 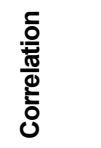 & $\begin{array}{l}\frac{0}{3} \\
\frac{2}{\pi} \\
\frac{1}{2}\end{array}$ & 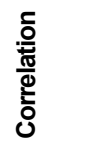 & $\frac{\varrho}{\frac{0}{\sigma}}$ & 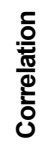 & $\begin{array}{l}\frac{0}{\pi} \\
\frac{\pi}{\pi} \\
\frac{1}{2}\end{array}$ & 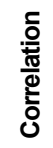 & $\begin{array}{l}\frac{0}{\frac{0}{\pi}} \\
\frac{2}{3} \\
\frac{1}{2}\end{array}$ & 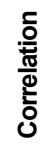 & $\begin{array}{l}\frac{0}{2} \\
\frac{2}{\pi} \\
\frac{1}{2}\end{array}$ \\
\hline v96 & 0.5200 & $<0.000$ v93 & -0.5001 & $<0.000$ & & & & & & \\
\hline v105 & 0.4520 & $<0.000$ v90 & -0.5166 & $<0.000$ & & & & & & \\
\hline v98 & 0.3504 & $<0.000$ v89 & -0.6297 & $<0.000$ & & & & & & \\
\hline v94 & 0.3090 & $<0.001$ & & & & & & & & \\
\hline v95 & 0.3049 & $<0.001$ & & & & & & & & \\
\hline v101 & 0.2966 & $<0.001$ & & & & & & & & \\
\hline
\end{tabular}

Loadings, correlation between principal components and the variables (Abdi \& Williams, 2010); strong/moderate correlation (considering values above 0.5 ); only variables with significant correlation $(\alpha>0.05)$ are presented.

Table 6. Description of variables in the second section that had a moderate/strong correlation with the principal components.

\begin{tabular}{|c|c|}
\hline \multicolumn{2}{|r|}{$\begin{array}{l}\text { Description of variables in the second section that had a moderate/strong correlation } \\
\text { with the principal components (Factors than can facilitate and encourage the } \\
\text { practices of patent development and academic entrepreneurship in the university) }\end{array}$} \\
\hline v102 & $\begin{array}{l}\text { The dissemination of information for further clarification on the assistance of } \\
\text { Brazilian development institutions (for example: FINEP; FACEPE; SENAI, BNDES) }\end{array}$ \\
\hline v92 & $\begin{array}{l}\text { Support of a specific team in the TIC for the marketing of the portfolio and } \\
\text { technological activities of the university }\end{array}$ \\
\hline v91 & $\begin{array}{l}\text { The existence of a specific team in the TTO with employees dedicated to the } \\
\text { marketing of the set of technologies that the university has }\end{array}$ \\
\hline v103 & Incentive via development agencies through thematic calls \\
\hline v93 & Support of a team for negotiating activities in the TTO \\
\hline v104 & $\begin{array}{l}\text { Increased frequency of successful TT cases via patent licensing between university } \\
\text { and industry }\end{array}$ \\
\hline v90 & $\begin{array}{l}\text { Promotion, by the TTO, of incentives for researchers to develop research for the } \\
\text { purpose of commercializing/licensing technologies with companies }\end{array}$ \\
\hline v99 & There must be a constant university-industry interaction through research groups \\
\hline v97 & Companies should look for universities to engage in partnerships. \\
\hline v89 & $\begin{array}{l}\text { Promotion, by the TTO, of incentives for researchers to develop projects together } \\
\text { with companies }\end{array}$ \\
\hline v100 & $\begin{array}{l}\text { Increased interest from the researcher in filing patent applications together with } \\
\text { companies }\end{array}$ \\
\hline v96 & $\begin{array}{l}\text { Researchers from Brazilian universities should interact with researchers from foreign } \\
\text { universities to increase the possibility of developing high-quality patents }\end{array}$ \\
\hline V98 & Researchers in the university should look for companies to engage in partnerships. \\
\hline V94 & Increased interest from the researcher in developing RD\&I projects \\
\hline V105 & Increased agility in the process of analysis and granting of patents by the INPI \\
\hline V101 & Companies located close to the university \\
\hline
\end{tabular}

The variables that were most correlated with the principal components are in bold type. 


\section{Discussion}

It is prudent to point out that this study only enables statistical inference for the population studied, that is, patent inventors and Research Productivity fellows that did not develop patents, both from UFPE and UFRPE.

The first section of the questionnaire was able to explain around $65 \%$ of the data variance using four principal components (Chart 3). It is noteworthy the fact that the first component presents variables that suggest the need for greater support from the university and TTO improvements, confirming the indication of TTO demands as being relevant (Siegel et al., 2003; Oliveira, 2011; Tian, 2015). More specifically, complaints related to the lack of TTO technological marketing and negotiation professionals were reported. The lack of experts in commercialization and negotiation strategies is a problem known in the literature, as well as the need to develop technology commercialization strategies (Siegel et al., 2007, 2003).

In this regard, university managers should promote the creation of an organizational structure, an environment and a structure that favor the development of the TTO activities. To do so, the TTOs need a strategic unit with activities oriented to academic entrepreneurship, especially trade negotiations (Weckowska, 2015). The TTO serves as an intermediary between the university and the industry (Markman et al., 2005); therefore, the skills required for a TTO manager seems to be more compatible with an experienced market professional than with a researcher traditionally oriented to the academia, given that one of the tasks of this professional will be to intermediate the university-market duality, reconciling the cultures of these different environments (Muscio, 2010). With regard to patents, the actions in UFPE's TTO have been fickle over the years. This was probably related to both the management of the university and the responsible body and the work methodology employed by it (information collected from UFPE's TTO, currently a board directly linked to the dean's office).

However, considering the panorama of the innovation system in the Northeast region, it is necessary to consider that there are great difficulties that limit the development and the flow of technology to the productive sector because of the little interaction and technological demand of local companies (Fernandes et al., 2011). On the other hand, the results show that a significant part of the issues indicated by researchers as obstacles to the practice of developing patents are internal issues of the university.

According to Wang \& Guan (2010), there must be a formal and constant dialogue between the ISTs and the industry in order to understand technological demands through the broadening of the knowledge on market needs. With this, it is possible to understand that academic research will hardly draw the interest of the industry if the academia does not put an effort into understanding their demands.

In this paper, $47.8 \%$ (44 out of 92) of patent inventors developed projects together with private institutions (Table 2). However, neither of the universities have done patent licensing yet. Thus, it is possible that effective (successful) interactions between researchers and companies are occurring through other TT channels (including informal relations). The occurrence of this type of interaction is mentioned in the literature as a way of getting around academic bureaucracy and is a barrier to the university-industry interaction in the perspective of TTO directors, entrepreneurs and researchers (Siegel et al., 2003).

With regard to the late occurrence of technology licensing, both the literature and the Innovation Law point to the TTOs as responsible in the sense that the commercialization of technologies developed in the university depends on their efforts 
and skills (Siegel et al., 2003; Jensen et al., 2003; Markman et al., 2005; Decter et al., 2007). This observation suggests that the TTO performance in executing its attributions (especially technology licensing) affects the motivation of researchers for academic patenting in the sense of creating opportunities and developing partnerships. It seems reasonable to assume that support and incentive from the university, in addition to the structuring of institutional bodies to support the researcher in the patenting practice, that is, the TTO, help motivate researchers. This applies to the contexts of other countries (Baldini et al., 2007; Tian, 2015) as well as to the Brazilian context (Oliveira, 2011). However, the TT and technological absorption issues in less technologically dynamic economies such as the state of Pernambuco involve other factors that are out of reach for a TIC - such as efforts and measures involving the spheres of government.

The second section of the questionnaire was able to explain around $75 \%$ of the variance of the data set using five principal components (Chart 5). It is noteworthy the fact that the first principal component presents variables that suggest TTO improvements, indicating the importance of the performance of this body and corroborating Brazilian (Dias \& Porto, 2013; Oliveira, 2011) and foreign (Baldini et al., 2007; Tian, 2015) studies.

In the case of Pernambuco, with regard to the field of engineering that interact with the electricity sector, most university-industry relationships are not constant and usually last the duration of the project (two to four years). This makes it difficult to develop projects with a high technological content and potential in terms of intellectual property. In addition, especially regarding patent development, large local electricity companies argue that internal rules require exclusivity of patent ownership, what may pressure researchers to give technological information to companies (Barbosa et al., 2016), inducing, thus, informal means of TT.

Considering the UFPE and UFRPE case, the fact that the first component of both sections of the questionnaire are related to variables associated with TTO endorses the importance of this body to the motivation for patent development in the university, which is corroborated by studies developed for other contexts (Baldini et al., 2007; Oliveira, 2011; Tian, 2015; Liu et al., 2016).

The importance of strengthening this body is highlighted also with regard to using other TT channels (De Fuentes \& Dutrénit, 2012), which is in line with the idea that researchers may feel more motivated to file patent applications when services and teams of experts are available to increase the possibilities of TT through this or through other TT channels.

In recent years, there has been an increase in the number of patent applications filed by Brazilian universities. This phenomenon has been celebrated, mirrored mainly in what occurs in universities in developed countries. However, unlike what happens in those countries - where universities have more financial resources to invest in intellectual property - the costs of filing and maintaining patent applications in developing countries can impact the budget of universities. With respect to patent applications, some researchers from UFPE reported a delay of around 4 months in filing a patent application due to the lack of resources to cover the application fee (according to the information collected).

Only a small portion of UFPE's applications was carried out jointly with companies (for example, with CELPE, the local electricity distribution company). Hence, most costs with filing and the annual maintenance of applications are covered by the university itself. In the case of UFRPE, joint applications have been filed only with other Brazilian TTOs thus far. Besides, in both universities, the ones who apply for the patent are the 
ones who bear all the costs. Therefore, the costs tend to be covered by those who are interested in applying.

The fact that the number of patent applications is higher than the number of licensed patents is something expected (Brito \& Fausto, 2015). However, when the number of non-commercially exploited patents is much higher, this can become a waste of public resources. Therefore, it is necessary to establish criteria for evaluating the economic and commercial viability of patents, a practice that is not yet present neither in the UFPE and UFRPE TTOs nor in other TTOs in the country, but present in English and Canadian universities (Brito \& Fausto, 2015).

Other TTOs from universities in the Southeast region of the country, such as UFABC (Federal University of the ABC) have measures such as: market analysis, maturity assessment, economic viability, business modeling, mapping of potential partners, priority partners, scope of the potential market and companies potentially interested in acquiring technologies. Such activities reveal the proactive action of TTOs, increasing the chances of TT from the university to the industry.

The fact that TTOs in universities in the Northeast region do not practice a leveling of the technologies prior to filing patent applications makes them a high-risk investment for universities, since they can be allocating resources to the protection of technologies with a low market potential.

As a limitation of the study, it is noteworthy that the most appropriate situation would be to consider top inventors to apply the questionnaire, since their response has greater weight. However, even with most respondents having filed one or two patent applications, around $55 \%$ were the first-listed inventors in the application (Chart 1). Furthermore, out of the population of researchers that filed at least three patent applications, about $70 \%$ participated in the survey, sustaining, thus, the relevance of the results.

\section{Conclusion}

The literature allows us to understand that the Northeast region is characterized by low infrastructure, limited S\&T density (Lima \& Fernandes, 2009) and low demand for technology by the productive sector, which reduces the technological dynamism of the economy (Fernandes et al., 2011). These factors alone create an environment that disadvantages the region with respect to increase research (basic and applied) capacity, especially regarding raising funds via public calls and demand from more technologically dynamic companies. In addition, there is the low synergy between the players in the regional innovation system. On the other hand, regional companies do not demand the technologies developed in the local TTOs, dismissing more frequent interactions. In some cases, however, the TICs do not offer technologies that are interesting for companies due to not monitoring the technological issues faced by them, that is, their specific demands. The combination of those factors makes it difficult and limits the interest in using formal TT channels (especially patents) and intensifies the challenge of local TTOs.

With regard to our objectives, the following conclusions must be highlighted:

(i) according to researchers, the factors that serve as barriers to the development of patents in the university are related to: (1) the lack of support, the culture of the university and the lack of support teams in the tic; (2) the low return and relevance given to the researcher's career and the reduced importance given by institutions and evaluation bodies, despite the recent advances observed in this direction; 
(3) little knowledge of the researcher about patents - traditionalism in scientific dissemination; and (4) the choice of other TT channels, given the little interest of researchers and limited openness to developing RD\&I projects;

(ii) on the other hand, the main motivations of researchers for developing patents in the university are related to: (1) the existence of support teams and pro-activity in the TTO; (2) the increased interest from researchers (universities) and companies in the university-industry interaction; (3) the existence of success cases in the university, and the increased agility in granting patents; (4) the increased interest from researchers in RD\&I projects, especially jointly with other TTOs; and (5) the location of companies close to the university.

In the literature reviewed by the present study, multiple dimensions for the interest of researchers in developing patents are highlighted. One of these dimensions regards the activities performed by the TTO, which has been corroborated by this study. In addition, there is also the existence of individual interests of the researcher such as improving their own curriculum, as observed by Oliveira (2011).

The results also endorse, even if indirectly, the existence of a limitation at the local level (low demand for technology due to the low technological dynamism of local companies), and the issue of the lack of a culture involving different TT channels (especially patents) and TTOs that are either not very active or offer little support to innovative activities in the university. These issues constitute the scenario of the region where the state of Pernambuco is located in, being distinguished not only from the Southeast region of Brazil but also from the other countries aforementioned. However, the results also reinforce the idea that efficiency and effectiveness of the support offered by UFPE's and UFRPE's respective TICs are factors closely related to the motivation of researchers for developing patents in the university, due to its relation with success in TT.

It is suggested the study of the motivation for using other Technology Transfer channels such as R\&D projects, consultancies and informal interactions. In addition, it is also suggested the study of variables that discriminate the profiles of researchers according to their field; for example, patent inventors from Engineering, Chemistry or Pharmaceutical Sciences. Such variables may indicate specific demands of these researchers.

Future studies can explore other statistical methods (such as discriminant analysis, random forest, regression analysis, structural equation modeling and artificial neural networks) to answer other questions. It is emphasized that databases of larger populations may favor predictive analyses, including cross-validation, given the trend of greater variability in the data.

Finally, it is understood that this is a subject that requires a more in-depth analysis, a broadening of its both qualitative and quantitative analysis, and discussions with player in the spheres of government, universities and companies. It is also necessary to investigate the preference of researchers for other TT channels, including the informal ones.

\section{References}

Abdi, H., \& Williams, L. J. (2010). Principal component analysis. Wiley Interdisciplinary Reviews: Computational Statistics, 2(4), 433-459. http://dx.doi.org/10.1002/wics.101. 
Acs, Z. J., Anselin, L., \& Varga, A. (2002). Patents and innovation counts as measures of regional production of new knowledge. Research Policy, 31(7), 1069-1085. http://dx.doi.org/10.1016/S0048-7333(01)00184-6.

Agrawal, A., \& Henderson, R. (2002). Putting patents in context: exploring knowledge transfer from MIT. Management Science, 48(1), 44-60. http://dx.doi.org/10.1287/mnsc.48.1.44.14279.

Arza, V., De Fuentes, C., Dutrénit, G., \& Vazquez, C. (2015). Channels and benefits of interactions between public research organizations and industry: comparing country cases in Africa, Asia, and Latin America. In E. Albuquerque, W. Suzigan, G. Kruss \& K. Lee (Eds.), Developing national systems of innovation: university-industry interactions in the global south (pp. 165-193). United Kingdom: Edward Elgar Publishing. http://dx.doi.org/10.4337/9781784711108.00015.

Association of University Technology Managers - AUTM. (2014). Highlights of AUTM's U.S. Licensing Activity Survey, FY2014. Washington: AUTM.

Association of University Technology Managers - AUTM. (2016). Retrieved in 2016, September 22, from http://www.autm.net/

Baldini, N., Grimaldi, R., \& Sobrero, M. (2007). To patent or not to patent? A survey of Italian inventors on motivations, incentives, and obstacles to university patenting. Scientometrics, 70(2), 333-354. http://dx.doi.org/10.1007/s11192-007-0206-5.

Barbosa, M. R., Lima, J. P. R., \& Fernandes, A. C. (2016). A interação universidades-empresas e o processo de inovação em Pernambuco: o caso da Engenharia Elétrica e o setor de eletricidade e gás. Ensaios FEE, 37(3), 769-800.

Bolfarine, H., \& Bussab, W. O. (2005). Elementos de amostragem. São Paulo: Blucher.

Bramwell, A., \& Wolfe, D. A. (2008). Universities and regional economic development: The entrepreneurial University of Waterloo. Research Policy, 37(8), 1175-1187. http://dx.doi.org/10.1016/j.respol.2008.04.016.

Brasil. (2004, 3 de dezembro). Lei no 10.973, de 2 de dezembro de 2004. Dispõe sobre incentivos à inovação e à pesquisa científica e tecnológica no ambiente produtivo e dá outras providências. Brasília: Diário Oficial da República Federativa do Brasil.

Breznitz, S. M., \& Feldman, M. P. (2012). The engaged university. The Journal of Technology Transfer, 37(2), 139-157. http://dx.doi.org/10.1007/s10961-010-9183-6.

Brito, E. V., \& Fausto, D. A. (2015). Critérios utilizados por universidades públicas para o abandono de patentes e de pedidos de patentes não licenciados. Revista iPecege, 1(2), 147-168. http://dx.doi.org/10.22167/r.ipecege.2015.2.147.

Centro de Gestão e Estudos Estratégicos - CGEE. (2014). Plano de ciência, tecnologia e inovação para o desenvolvimento sustentável do nordeste brasileiro (Série Documentos Técnicos, No. 22). Brasília.

Closs, L., Ferreira, G., Sampaio, C., \& Perin, M. (2012). Intervenientes na transferência de tecnologia universidade-empresa: o caso PUCRS. Revista de Administração Contemporânea, 16(1), 59-78. http://dx.doi.org/10.1590/S1415-65552012000100005.

Cohen, W. M., Nelson, R. R., \& Walsh, J. P. (2002). Links and impacts: the influence of public research on industrial R\&D. Management Science, 48(1), 1-23. http://dx.doi.org/10.1287/mnsc.48.1.1.14273.

Cowan, R., \& Zinovyeva, N. (2013). University effects on regional innovation. Research Policy, 42(3), 788-800. http://dx.doi.org/10.1016/j.respol.2012.10.001.

Czarnitzki, D., Hussinger, K., \& Schneider, C. (2011). Commercializing academic research: the quality of faculty patenting. Industrial and Corporate Change, 20(5), 1403-1437. http://dx.doi.org/10.1093/icc/dtr034. 
De Fuentes, C., \& Dutrénit, G. (2012). Best channels of academia-industry interaction for longterm benefit. Research Policy, 41(9), 1666-1682.

http://dx.doi.org/10.1016/j.respol.2012.03.026.

Decter, M., Bennett, D., \& Leseure, M. (2007). University to business technology transfer-UK and USA comparisons. Technovation, 27(3), 145-155. http://dx.doi.org/10.1016/j.technovation.2006.02.001.

Dias, A. A., \& Porto, G. S. (2013). Gestão de transferência de tecnologia na Inova Unicamp. Revista de Administração Contemporânea, 17(3), 263-284. http://dx.doi.org/10.1590/S1415-65552013000300002.

Fernandes, A. C., Souza, B. C., \& Silva, A. S. (2011). Demanda e oferta de tecnologia e conhecimento em região periférica: a interação universidade-empresa no Nordeste Brasileiro. In W. Suzigan, E. M. Albuquerque \& S. A. F. Cario (Eds.), Em busca da inovação: interação universidade-empresa no Brasil. Belo Horizonte: Autêntica.

Ferreira, M. H. W. (2015). Análise da produção científica e tecnológica do programa de pósgraduação em ciências farmacêuticas da UFPE (Dissertação de mestrado). Universidade Federal de Pernambuco, Recife.

Foltz, J. D., Barham, B. L., Chavas, J., \& Kim, K. (2012). Efficiency and technological change at US research universities. Journal of Productivity Analysis, 37(2), 171-186. http://dx.doi.org/10.1007/s11123-011-0249-8.

Gallini, N. T. (2002). The economics of patents: lessons from recent U.S. patent reform. The Journal of Economic Perspectives, 16(2), 131-154. http://dx.doi.org/10.1257/0895330027292.

Galván, R. G. (2017). Patentamiento universitario e innovación en México, país en desarrollo: teoría y política. Revista de la Educación Superior, 46(184), 77-96. http://dx.doi.org/10.1016/j.resu.2017.11.001.

Gil, A. C. (2008). Como elaborar projetos de pesquisa (5. ed.). São Paulo: Atlas.

Göktepe, D., \& Mahagaonkar, P. (2008). What do scientists want: money or fame? (Jena Economic Research Papers, No. 032). Jena: University Jena.

Gullo, L. M. G., \& Guerrante, R. S. (2006). Maiores depositantes de pedidos de patentes no Brasil, com prioridade brasileira (publicados entre 1999 e 2003). Rio de Janeiro: INPI.

Haase, H., Araujo, E. C., \& Dias, J. (2005). Inovações vistas pelas patentes: exigências frente às novas funções das universidade. Revista Brasileira de Inovação, 4(2), 329-362. http://dx.doi.org/10.20396/rbi.v4i2.8648916.

Hair, J. F., Jr., Black, W. C., Babin, B. J., Anderson, R. E., \& Tatham, R. L. (2009). Análise multivariada de dados (6. ed.). Porto Alegre: Bookman.

Henderson, R., Jaffe, A. B., \& Trajtenberg, M. (1998). Universities as a source of commercial technology: a detailed analysis of university patenting, 1965-1988. The Review of Economics and Statistics, 80(1), 119-127. http://dx.doi.org/10.1162/003465398557221.

Hora, H. R. M., Monteiro, G. T. R., \& Arica, J. (2010). Confiabilidade em questionários para qualidade: um estudo com o coeficiente alfa de Cronbach. Produto \& Produção, 11(2), 85103. http://dx.doi.org/10.22456/1983-8026.9321.

Huszár, S., Prónay, S., \& Buzás, N. (2016). Examining the differences between the motivations of traditional and entrepreneurial scientists. Journal of Innovation and Entrepreneurship, 5(25), 1-22. http://dx.doi.org/10.1186/s13731-016-0054-8.

Jensen, R., Thursby, J. G., \& Thursby, M. C. (2003). Disclosure and licensing of university inventions: 'The best we can do with the ${ }^{\star *}$ t we get to work with'. International Journal of Industrial Organization, 21(9), 1271-1300. http://dx.doi.org/10.1016/S0167-7187(03)00083-3.

Jolliffe, I. T. (1986). Principal component analysis. New York: Springer.

Jolliffe, I. T. (2002). Principal component analysis (2nd ed.). New York: Springer. 
Kaiser, H. F. (1958). The varimax criterion for analytic rotation in factor analysis. Psychometrika, 23(3), 187-200. http://dx.doi.org/10.1007/BF02289233.

Kalutkiewicz, M. J., \& Ehman, R. L. (2014). Patents as proxies: NIH hubs of innovation. Nature Biotechnology, 32(6), 536-537. http://dx.doi.org/10.1038/nbt.2917. PMid:24911494.

Leydesdorff, L., \& Meyer, M. (2010). The decline of university patenting and the end of the Bayh-Dole effect. Scientometrics, 83(2), 355-362. http://dx.doi.org/10.1007/s11192-0090001-6. PMid:22844165.

Li, D., Azoulay, P., \& Sampat, B. (2017). The applied value of public investments in biomedical research. Science, 356(6333), 78-81. http://dx.doi.org/10.1126/science.aal0010. PMid:28360137.

Lima, J. P. R., \& Fernandes, A. C. (2009). Demandas e ofertas tecnológicas em economias retardatárias: anotações a partir de dois segmentos econômicos no Nordeste brasileiro. Revista Brasileira de Inovação, 8(2), 303-340. http://dx.doi.org/10.20396/rbi.v8i2.8648983.

Liu, Y., Tan, L., \& Cheng, Y. (2016). University Patent Licensing and Its Contribution to China's National Innovation System. In: D. Prud'homme \& H. Song (Eds.), Economic Impacts of Intellectual Property-Conditioned Government Incentives (259-277). Singapore: Springer Science Business Media Singapore.

Mardia, K. V., Kent, J. T., \& Bibby, J. M. (1979). Multivariate analysis. London: Academic Press.

Markman, G. D., Phan, P. H., Balkin, D. B., \& Gianiodis, P. T. (2005). Entrepreneurship and university-based technology transfer. Journal of Business Venturing, 20(2), 241-263. http://dx.doi.org/10.1016/j.jbusvent.2003.12.003.

Maroco, J., \& Garcia-Marques, T. (2006). Qual a fiabilidade do alfa de Cronbach? Questões antigas e soluções modernas? Laboratório de Psicologia, 4(1), 65-90. http://dx.doi.org/10.14417/lp.763.

Mendes, C. D. S., Gullo, L. M. G., \& Guerrante, R. D. S. (2011). Principais titulares de pedidos de patentes no Brasil, com prioridade brasileira: depositados no período de 2004 a 2008. Rio de Janeiro: INPI.

Mowery, D. C., Nelson, R. R., Sampat, B. N., \& Ziedonis, A. A. (2001). The growth of patenting and licensing by U.S. universities: an assessment of the effects of the Bayh-Dole act of 1980. Research Policy, 30(1), 99-119. http://dx.doi.org/10.1016/S0048-7333(99)00100-6.

Mowery, D. C., Sampat, B. N., \& Ziedonis, A. A. (2002). Learning to patent: institutional experience, learning, and the characteristics of US university patents after the Bayh-Dole Act, 1981-1992. Management Science, 48(1), 73-89. http://dx.doi.org/10.1287/mnsc.48.1.73.14278.

Muscio, A. (2010). What drives the university use of technology transfer offices? Evidence from Italy. The Journal of Technology Transfer, 35(2), 181-202. http://dx.doi.org/10.1007/s10961-009-9121-7.

Oliveira, R. M. O. (2011). Proteção e comercialização da pesquisa acadêmica do Brasil: motivações e percepções dos inventores (Tese de doutorado). Universidade Estadual de Campinas, Campinas.

Organisation for Economic Co-operation and Development - OECD. (2004). Patents, innovation and economic performance OECD conference proceedings. Paris: OECD Publishing.

Osano, H. M. (2017). Universities and development of regional innovation ecosystems: case of Kenya. WTR, 6, 113-129. http://dx.doi.org/10.7165/wtr17a1115.17.

Parente, R., Petrone, M., \& Cerrato, D. (2011). Co-patenting between university and business companies: evidence from Italy. In 56th International Council for Small Business (ICSB) World Conference 2011: Back to the Future: Changes in Perspectives of Global Entrepreneurship and Innovation. Stockholm: International Council for Small Business. 
Park, W. G. (2008). International patent protection: 1960-2005. Research Policy, 37(4), 761766. http://dx.doi.org/10.1016/j.respol.2008.01.006.

Pavitt, K. (1984). Sectoral patterns of technical change: towards a taxonomy and a theory. Research Policy, 13(6), 343-373. http://dx.doi.org/10.1016/0048-7333(84)90018-0.

Pinho, M., \& Fernandes, A. C. (2015). Relevance of university-industry links for firms from developing countries: exploring different surveys. In E. Albuquerque, W. Suzigan, G. Kruss \& K. Lee (Eds.), Developing national systems of innovation: university-industry interactions in the global south (pp. 145-163). London: Edward Elgar Publishing/IDRC.

Póvoa, L. M. C. (2008). Patentes de universidades e institutos públicos de pesquisa e a transferência de tecnologia para as empresas no Brasil (Tese de doutorado). Universidade Federal de Minas Gerais, Belo Horizonte.

Póvoa, L. M. C., \& Rapini, M. S. (2010). Technology transfer from universities and public research institutes to firms in Brazil: what is transferred and how the transfer is made. Science \& Public Policy, 37(2), 147-159. http://dx.doi.org/10.3152/030234210X496619.

Ragavan, S. (2012). Patent and trade disparities in developing countries. Oxford: Oxford University Press. http://dx.doi.org/10.1093/acprof:oso/9780199840670.001.0001.

Saragossi, S., \& Potterie, B. P. (2003). What patent data reveal about universities: the case of Belgium. The Journal of Technology Transfer, 28(1), 47-51. http://dx.doi.org/10.1023/A:1021678719567.

Sharma, P., \& Tripathi, R. C. (2017). Patent citation: a technique for measuring the knowledge flow of information and innovation. World Patent Information, 51, 31-42. http://dx.doi.org/10.1016/j.wpi.2017.11.002.

Siegel, D. S., Veugelers, R., \& Wright, M. (2007). Technology transfer offices and commercialization of university intellectual property: performance and policy implications. Oxford Review of Economic Policy, 23(4), 640-660.

Siegel, D. S., Waldman, D., \& Link, A. (2003). Assessing the impact of organizational practices on the relative productivity of university technology transfer offices: an exploratory study. Research Policy, 32(1), 27-48. http://dx.doi.org/10.1016/S0048-7333(01)00196-2.

Silva, K. (2014). Patentes acadêmicas no Brasil: um novo panorama de contribuição das universidades na via PCT (Dissertação de mestrado). Lisboa School of Economics \& Management, Lisboa, Portugal.

Tian, Y. (2015). From publishing to patenting: survey construction of Swedish academics' motivations (Master theses). University of Gothenburg, Gothenburg, Sweden.

Torkomian, A. (2009). Panorama dos núcleos de inovação tecnológica no Brasil. In M. Santos, P. Toledo \& R. Lotufo (Eds.), Transferência de tecnologia: estratégias para a estruturação de núcleos de inovação tecnológica (pp. 21-37).Campinas: Komedi.

United Nations Industrial Development Organization - UNIDO. (2006). The role of intellectual property rights in technology transfer and economic growth: theory and evidence (Working Papers). Vienna: UNIDO.

Van Gils, M., Vissers, G., \& Wit, J. (2009). Selecting the right channel for knowledge transfer between industry and science: consider the R\&D-activity. European Journal of Innovation Management, 12(4), 492-511. http://dx.doi.org/10.1108/14601060910996936.

Wang, G., \& Guan, J. (2010). The role of patenting activity for scientific research: a study of academic inventors from China's nanotechnology. Journal of Informetrics, 4(3), 338-350. http://dx.doi.org/10.1016/j.joi.2010.02.002.

Weckowska, D. M. (2015). Learning in university technology transfer offices: transactionsfocused and relations-focused approaches to commercialization of academic research. Technovation, 41-42, 62-74. http://dx.doi.org/10.1016/j.technovation.2014.11.003. 
Wong, P., Ho, Y., \& Singh, A. (2007). Towards an "entrepreneurial university" model to support knowledge-based economic development: the case of the National University of Singapore. World Development, 35(6), 941-958. http://dx.doi.org/10.1016/j.worlddev.2006.05.007.

Zuniga, P. (2011). The state of patenting at research institutions in developing countries: policy approaches and practices (Working Paper, No. 4). Geneva: WIPO. Retrieved in 2016, September 21, from http://www.wipo.int/edocs/pubdocs/en/wipo_pub_econstat_wp_4.pdf 